\title{
High Speed Synthesis of Pyrazolones using Microwave-Assisted Neat Reaction Technology
}

\author{
Sarbani Pal,* Jyoti Mareddy and Nalla Suneetha Devi \\ Department of Chemistry, MNR Degree and Post Graduate College, Kukatpally, Hyderabad-500072, India
}

\begin{abstract}
Descrevemos uma síntese rápida e pratica de pirazolonas, na ausência de solvente, sob irradiação de microondas. Esta metodologia sintética envolve a reação de $\beta$-cetoésteres com hidrazinas substituídas e não-substituídas e oferece uma preparação simples e direta de diferentes pirazolonas com alta regioseletividade. Essas pirazolonas podem existir em diferentes formas tautoméricas em solução e o anel 2-aril-pirazol-3-ona permanece torcido em relação ao plano da pirazolona no estado cristalino. O mecanismo da reação é proposto levando em conta a regiosseletividade. Uma das pirazolonas obtidas nesse processo foi usada na preparação de um derivado espirociclohexanona de significativo potencial biológico.
\end{abstract}

\begin{abstract}
A high speed, solvent-free, and practical synthesis of pyrazolones under microwave irradiation is described. This greener synthetic methodology involves the reaction of $\beta$-keto ester with substituted or unsubstituted hydrazine and provides a simple and straightforward one-pot approach for the synthesis of a variety of pyrazolone derivatives with high regioselectivity. These pyrazolones can exist in different tautomeric forms in solution and the aryl ring of 2-aryl pyrazol-3-ones remain twisted with respect to the pyrazole plane in the crystal state. Mechanism of the reaction accounting the regioselectivity has been proposed. One of the pyrazolones obtained via this process was utilized to prepare a spirocyclohexanone derivative of potential biological significance.
\end{abstract}

Keywords: pyrazolone, $\beta$-keto ester, hydrazine, microwave

\section{Introduction}

Pyrazolone moiety (a five-membered lactam ring containing two nitrogens and ketone in the same molecule or alternatively a derivative of pyrazole possessing an additional carbonyl/hydroxy group) has been the focus of medicinal chemists for over last 100 years because of the outstanding pharmacological properties shown by several of its derivatives ${ }^{1}$ e.g. ampyrone, metamizole etc. Soon after the discovery of phenyl hydrazine (I, Figure 1) by Emil Fischer in 1883, Ludwig Knorr (Fischer's assistant) attempted to synthesize a quinoline derivative. The product however, isolated after methylation was found to be a pyrazolone derivative and was named as antipyrin or phenazone (II, Figure 1). ${ }^{2}$ Because of its promising antipyretic and analgesic activities antipyrin was launched by Hoechst Pharmaceuticals. For the next 20 years, antipyrin became the most widely used drug in the world, proving highly successful for treating fever and flu like infections, until acetylsalicylic acid (aspirin) began to outsell it. ${ }^{3}$

*e-mail: sarbani277@yahoo.com
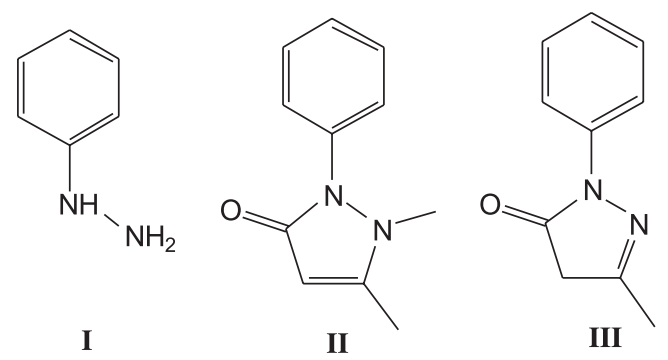

Figure 1. Structure of phenyl hydrazine (I), antipyrin (II) and MCI-186 (III).

Recently, a new pyrazolone compound III, edaravone (3-methyl-1-phenyl-2-pyrazolin-5-one, also known as MCI-186, Figure 1), has been developed as a promising drug for brain ischemia ${ }^{4,5}$ and has also been reported to be effective for myocardial ischemia. ${ }^{6}$ More recently, a series of pyrazolone derivatives have been synthesized as potent inhibitors of protease-resistant prion protein accumulation for the treatment of fatal neurodegenerative diseases. ${ }^{7}$ In view of their high medicinal value and due to our interest in the synthesis of compounds of potential pharmacological interest $\mathrm{t}^{8-10}$ we became interested in constructing a library based on pyrazolone scaffold. This library could potentially 
serve as a source of (i) pyrazolone based new chemical entities for biological screen, (ii) versatile intermediates to access a variety of biologically active heterocycles..$^{11-18}$

A number of methods have been developed for the preparation of pyrazolone derivatives. ${ }^{19,20}$ These methods are diverse, but frequently involve the condensation of a $\beta$-keto ester or $\beta$-keto aldehyde with substituted or unsubstituted hydrazines..$^{21,22}$ These methodologies, although utilized for the preparation of a variety of pyrazolones, often require the use of refluxing conditions and lengthy reaction time, ideally 3-10 h. Moreover, the use of excess solvent and its recovery can pose a major environmental problem especially in the large-scale synthesis. Due to the increased environmental consciousness throughout the world extensive efforts have been devoted to develop an alternate synthetic approach for biologically and synthetically important compounds. The microwave-assisted synthesis is one of the areas where substantial progress has been made. ${ }^{23}$ One of its noteworthy application has been demonstrated in the area of "neat reaction" which has become an emerging technology in green chemistry recently. ${ }^{24}$ "Neat reaction" is an alternative solventfree approach in which a mixture of reactants in the absence of solvent is irradiated under microwaves. It is mention worthy that the use of microwave eliminates the possibility of charring the reactants/products that might occur under conventional heating in the absence of a solvent. Thus, the striking features of microwave-assisted neat reaction include improved yield, shorter reaction time and easier work-up. Due to our interest in the solvent free synthesis of heterocyclic compounds of potential pharmacological significances ${ }^{25} \mathrm{we}$ decided to develop a solvent free synthesis of pyrazolones under microwave irradiation (Scheme 1). Recently, Mojtahedi and coworkers ${ }^{26}$ reported a similar synthesis of pyrazolones from $\beta$-keto esters and hydrazine. However, thier study was limited to the use of fewer numbers of hydrazines and more importantly, the report does not provide a detailed account of this methodology. Herein we report our detailed study on the solvent free synthesis of pyrazolones under microwave irradiation that includes (i) the key structural features of the compounds synthesized, (ii) mechanism of the reaction accounting the regioselectivity and (iii) application of this process towards the synthesis of compounds of medicinal value. The results of this study are summarized in Table 1.

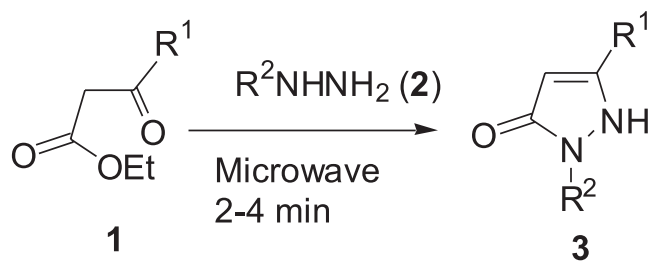

Scheme 1.

\section{Results and Discussion}

During the course of our studies we found that ethylacetoacetate (1a) reacted efficiently with phenyl hydrazine (2a), under microwave irradiation (power input $20 \%$ ), to provide pyrazol-3-one (3a) regioselectively in $67 \%$ yield (Entry 1, Table 1). This reaction was conducted for $2 \mathrm{~min}$ in the absence of any solvent. However, to improve the product yield, the same reaction was carried out for 4 min (Entry 2, Table 1) and the product yield was increased to $82 \%$. The yield was decreased when the reaction was conducted using increased power input for 4.0 min (Entry 3, Table 1) perhaps due to the partial decomposition of the product formed. In order to compare the present method with the conventional one ${ }^{21}$ the reaction of 1a with 2a was carried out in methanol under refluxing condition for $10 \mathrm{~h}$ when $\mathbf{3 a}$ was isolated in $88 \%$ yield (Entry 4, Table 1). It is therefore clear that the present method, although does not offer any significant advantages over the conventional method in terms of product nature and yield, can however, reduce the reaction time remarkably avoiding the use of solvent and prolonged heating conditions. Thus, this microwave reaction proved to be very practical and we therefore sought to explore the reaction scope further. A variety of pyrazolones (3b-i) were prepared regioselectively in fair to good yields (Entries 5-12, Table 1). While a particular regioisomer was isolated in all the cases, formation of traces amount of other regioisomer however, can not be ruled out completely as the yields of isolated products were not very high always. Since the reaction proceeds via stepwise elimination of water and ethanol (see later for mechanistic discussion) it was possible to form hydrazone intermediate as a side product. We however, failed to isolate any such intermediate except when hydrazine $\mathbf{2 c}$ was employed (see later). Nevertheless, the results from Table 1 show that $\beta$-keto esters ( $\mathbf{1 a}$ and $\mathbf{1 b})$ reacted efficiently with a variety of commercially available substituted / unsubstituted hydrazines (2) to provide the desired products. In a typical solvent-free microwave reaction, a mixture of the $\beta$-keto ester and hydrazine in a 1:1 ratio, was exposed to microwave irradiation (power input as indicated in Table 1) for 2-4 min (CAUTION: $\beta$-ketoesters are flammable and may catch fire during microwave heating). Upon completion, the reaction was allowed to reach room temperature, diluted with ethyl acetate (or ethyl acetate-petroleum ether) with vigorous stirring and the precipitate was collected by filtration. (It was observed that substantial amount of product was present in the filtrate which was isolated after reducing the volume of the filtrate and subsequent cooling followed by filtration). The product isolated was analyzed. 
Table 1. Microwave assisted synthesis of pyrazol-3-ones ${ }^{\mathrm{a}}$

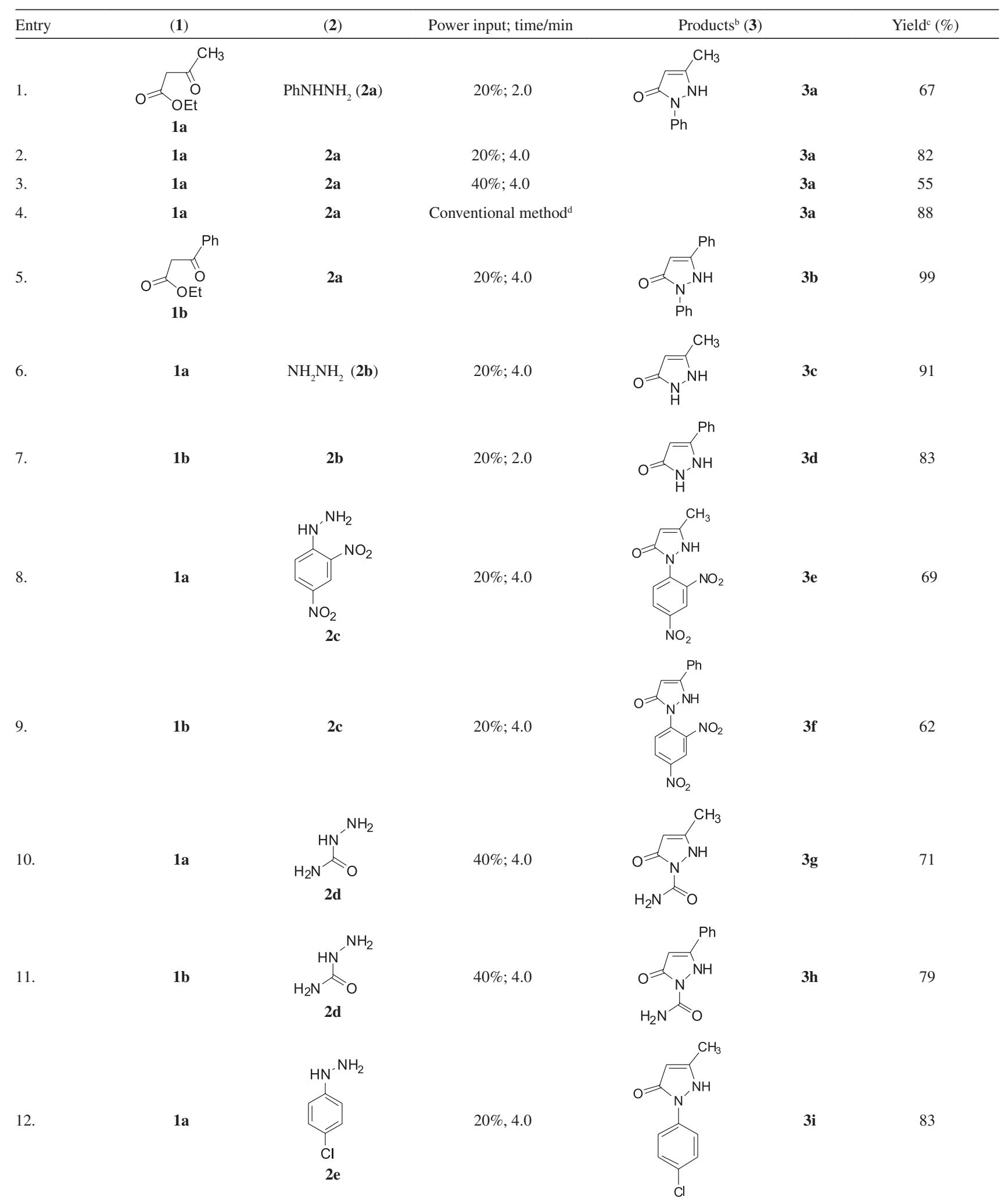

${ }^{\mathrm{a}}$ All the reactions were carried out using $\beta$-keto esters (1) and hydrazine (2) under microwave; ${ }^{\mathrm{b} I d e n t i f i e d ~ b y ~}{ }^{1} \mathrm{H}$ NMR, IR, Mass; ${ }^{\mathrm{C}}$ Isolated yields of pure product; ${ }^{\mathrm{d}}$ The reaction was carried out in refluxing $\mathrm{MeOH}$ for $10 \mathrm{~h}$. 
We have shown that the short reaction time, in combination with good yields can make microwave assisted reaction of hydrazines with $\beta$-ketoesters ideal for a rapid entry to pyrazolones. All the compounds synthesized are characterized by spectroscopic ( ${ }^{1} \mathrm{H}$ NMR, IR and MS) data. While determination of tautomeric composition of compound $\mathbf{3}$ is quite challenging as eight possible tautomeric forms need to be considered, interestingly, two major tautomeric forms of compound 3a was observed in two different solvents. For example, it exists as 1,2-dihydro pyrazolone (T-1, Figure 2) in DMSO and 2,4-dihydro form (T-2, Figure 2) in chloroform as indicated by ${ }^{1} \mathrm{H}$ NMR spectra (Figure 3). The olefinic proton of T-1 appeared at $5.36 \delta$ whereas the methylene hydrogens appeared at $3.43 \delta$ in case of T-2. Additionally, the NH proton of T-1 at $11.40 \delta$ was not observed incase of T-2 confirmed the absence of $\mathrm{NH}$ in the 2,4-dihydro form. Existence of two major tautomeric forms was also observed in case compound $\mathbf{3 b}$ (see ${ }^{1} \mathrm{H}$ NMR data in the experimental section). However, X-ray study on single crystal of 2-(4-chlorophenyl)-5-methyl-1,2-dihydro pyrazol-3-one (3i) indicates that 2-aryl pyrazol-3-ones<smiles>Cc1ccccc1</smiles>

$\mathrm{T}-1$ in DMSO<smiles>CC1=NN(c2ccccc2)C(=O)C1CCC(C)(C)C</smiles>

T -2 in $\mathrm{CHCl}_{3}$
Figure 2. Two major tautomeric forms of compound 3a in DMSO and $\mathrm{CHCl}_{3}$.
A) in DMSO- $d_{6}$

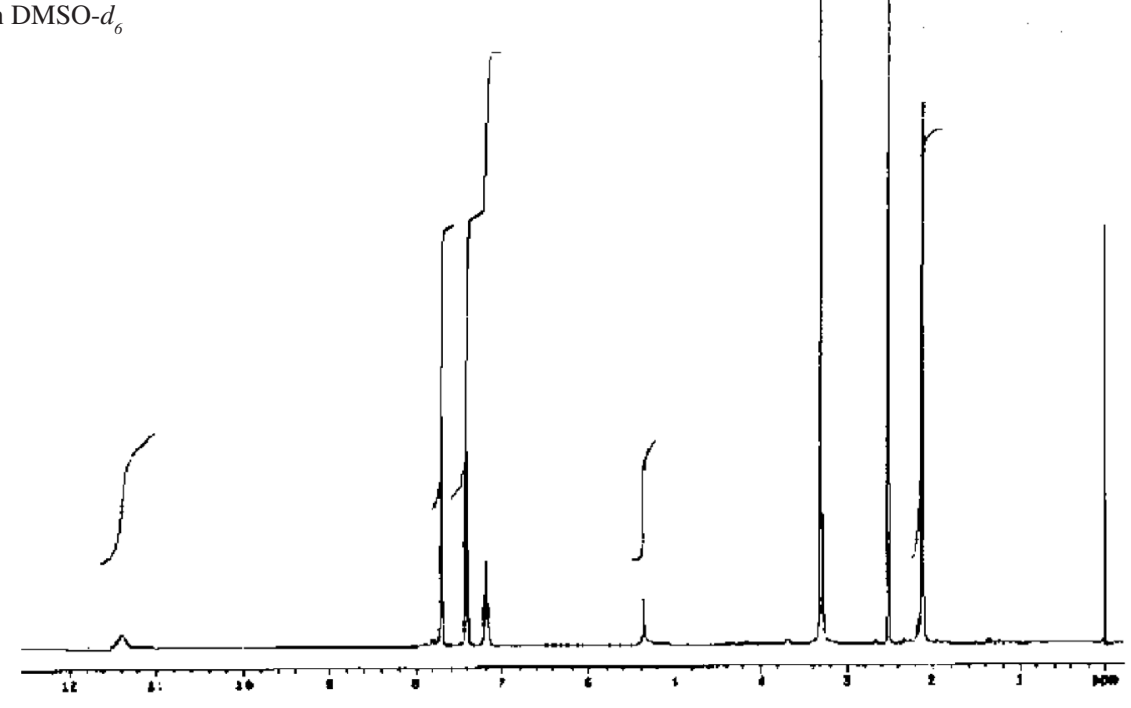

B) in $\mathrm{CDCl}_{3}$

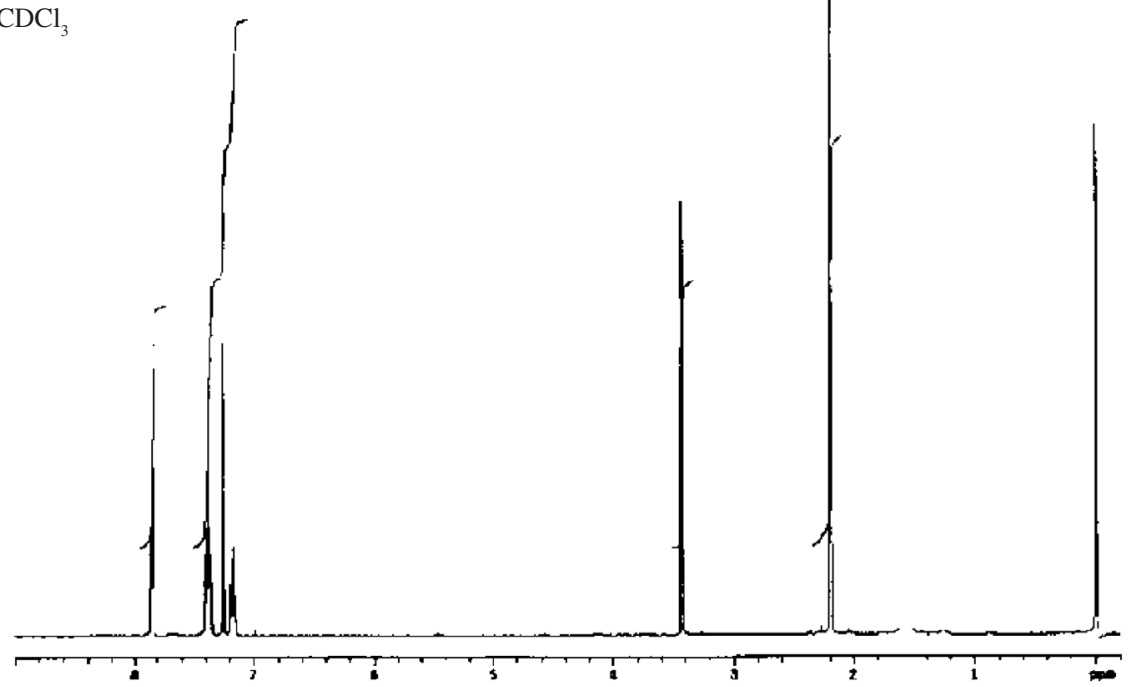

Figure 3. ${ }^{1} \mathrm{H}$ NMR spectra of $\mathbf{3 a}$. 
e.g. 3a-b, 3e-f and 3i exist as 1,2-dihydro form in crystal state. ${ }^{27}$ It is mention worthy that the aryl ring of all these 2-aryl pyrazol-3-ones remain twisted with respect to the pyrazole plane as indicated by the crystallographic data of $3 i$ [the dihedral angle between the pyrazole and benzene ring planes was found to be $\left.15.81(11)^{\circ}\right] .{ }^{27}$

Mechanistically, ${ }^{28}$ the present microwave assisted reaction of hydrazines with $\beta$-ketoesters proceeds via $(i)$ regioselective attack of the least hindered nitrogen atom of $\mathbf{2}$ on the ketone moiety of $\mathbf{1}$ followed by (ii) intramolecular cyclization involving the ester and the second nitrogen atom of hydrazine moiety to provide compound $\mathbf{3}$. This was supported by the isolation of hydrazone intermediate 3ee and $\mathbf{3 f f}$ (these products were isolated when the reaction was carried out for $1.0 \mathrm{~min}$., see experimental section for spectral data) as a side product during the reaction of 2,4-dinitrophenyl hydrazine (2c) with $\beta$-ketoesters (1) (Figure 4). Clearly, the regioselectivity of the reaction is governed by the higher reactivity of ketone moiety over ester $^{29}$ and least hindered nitrogen atom of $\mathbf{2}$. Additionally, the aryl group of hydrazine moiety seems to play a key role in the intramolecular cyclization process and presumably, the electron withdrawing effect of 2,4-dinitrophenyl group allowed us to isolate the hydrazone intermediate. Nevertheless, among the pyrazolone derivatives synthesized compound $\mathbf{3 a}$ showed analgesic activity in mice when dosed at $50 \mathrm{mg} \mathrm{kg}^{-1}$ as suspension in a $2 \%$ starch jelly. ${ }^{30}$ Additionally, compound $\mathbf{3 a}$ was utilized to prepare the spirocyclohexanone derivative $\mathbf{6}$ of potential biological significance according to a similar but modified procedure reported in the literature (Scheme 2). ${ }^{31}$ Thus compound 3a was converted to a diester derivative $\mathbf{4}$ as a result of Michael addition with excess of methylacrylate. The reaction was found to be clean and no side product arising from mono-adduct was detected in the reaction mixture. As indicated by our study that $\mathbf{3 a}$ can exist in two different tautomeric forms (T-1 and T-2) in solution depending on the nature of solvent used, it is therefore possible that 3a may exist as T-2 in DMF in the presence of
$\mathrm{NaH}$ and generates carbanion to undergo Michael addition with methylacrylate. Alternatively, $\mathrm{NaH}$ can generate an anion via deprotonation of $\mathbf{N H}$ of $\mathbf{T}-\mathbf{1}$ which in tern can provide the required carbanion as a result of resonance stabilization. The diester $\mathbf{4}$ on Dickmann condensation in the presence of a base afforded spirocyclohexyl- $\beta$ ketoester $\mathbf{5}$ which, on decarboxylation yielded the desired spiro compound $\mathbf{6}$.

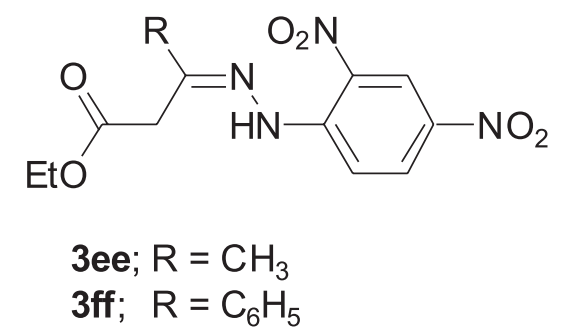

Figure 4. Hydrazone intermediates $\mathbf{3 e e}$ and $\mathbf{3 f f}$ isolated from the reaction of $2 \mathrm{c}$ with 1 .

\section{Conclusions}

In conclusion, a microwave-assisted rapid and one-pot synthesis of pyrazolone derivatives has been achieved under solvent-free conditions from commercially available starting materials. Merits and demerits of this process have been assessed. While this environmentally friendly method does not differ significantly from the conventional method in terms of product nature and yield, it however provides advantages, such as shorter reaction time, solvent-free conditions and minimal purification of the products. As suggested by spectral data that these pyrazolones can exist in two major tautomeric forms in solution. Experimental evidences suggest that the regioselectivity of this reaction is governed by the higher reactivity of ketone moiety over ester and least hindered nitrogen atom of substituted hydrazine. The utility of this process has been demonstrated in the preparation of a spirocyclohexanone derivative of potential biological significance. Further application of the present method is currently under investigation.

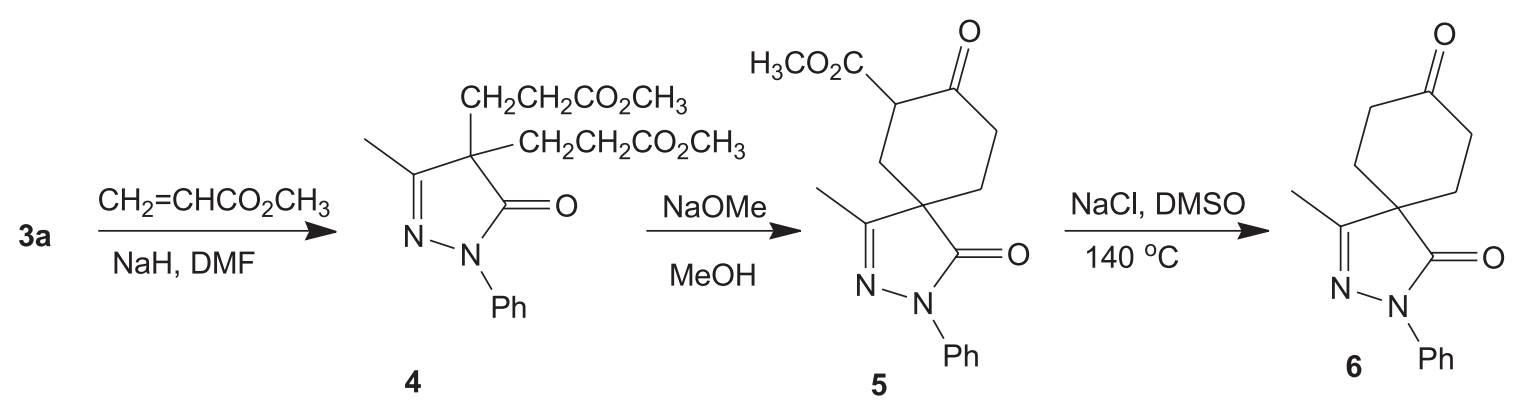

Scheme 2. Synthesis of spirocyclohexanone derivative. 


\section{Experimental}

\section{General methods}

Reactions were carried out using household micro oven (power consumption $1200 \mathrm{~W}$, microwave frequency 2450 $\mathrm{MHz}$ ) and monitored by thin layer chromatography (TLC) on silica gel plates ( 60 F254), visualizing with ultraviolet light or iodine spray. Column chromatography was performed on silica gel (60-120 mesh) using distilled petroleum ether and ethyl acetate. ${ }^{1} \mathrm{H}$ NMR spectra were determined either in $\mathrm{CDCl}_{3}$ or DMSO- $d_{6}$ solution on 400 or $200 \mathrm{MHz}$ spectrometers. Proton chemical shifts $(\delta)$ are relative to tetramethylsilane (TMS, $\delta=0.00$ ) as internal standard and expressed in ppm. Spin multiplicities are given as s (singlet), d (doublet) and $\mathrm{m}$ (multiplet) as well as b (broad). Coupling constants $(J)$ are given in hertz. Infrared spectra were recorded on a FTIR spectrometer. Melting points were determined by using melting point apparatus and are uncorrected. MS spectra were obtained on a JMS-D 300 spectrometer.

\section{Typical procedure for the preparation of $\mathbf{3 a}$}

A mixture of the ethyl acetoacetate $(0.98 \mathrm{~mL}$, $7.68 \mathrm{mmol})$ and phenylhydrazine hydrate $(0.72 \mathrm{~mL}$, $7.29 \mathrm{mmol}$ ) was exposed to microwave irradiation (power input 20\%) for $4.0 \mathrm{~min}$. Upon completion, the reaction mixture was allowed to reach room temperature, diluted with ethylacetate with vigorous stirring and the precipitate was collected by filtration. If the product is not precipitated out from the ethylacetate solution then volume of the solution need to be reduced under low vacuum and the resulting mixture should be allowed to stand under cold condition. The product isolated was analyzed.

\section{5-Methyl-2-phenyl-1,2-dihydro pyrazol-3-one (3a)} mp 125-127 ${ }^{\circ} \mathrm{C}\left(\operatorname{lit}^{21} 126-130{ }^{\circ} \mathrm{C}\right)$; IR (KBr) $v_{\max } / \mathrm{cm}^{-1}$ : 3127, 1597, 1525, 1498, 1454; ${ }^{1} \mathrm{H}$ NMR (400 MHz, DMSO- $\left.d_{6}\right) \delta 11.40(\mathrm{bs}, 1 \mathrm{H}), 7.71-7.69(\mathrm{~m}, 2 \mathrm{H}), 7.42-7.38(\mathrm{~m}$, $2 \mathrm{H}), 7.21-7.18(\mathrm{~m}, 1 \mathrm{H}), 5.36(\mathrm{~s}, 1 \mathrm{H}), 2.10(\mathrm{~s}, 3 \mathrm{H}) ;{ }^{13} \mathrm{C} \mathrm{NMR}$ $\left(50 \mathrm{MHz}, \mathrm{DMSO}-d_{6}\right) \delta 170.6,156.2,138.1,128.8(2 \mathrm{C}), 124.9$, 118.9 (2C), 43.1, 16.9; Mass (CI, m/z) $175(\mathrm{M}+1,100)$.

${ }^{1} \mathrm{H}$ NMR (400 MHz, $\left.\mathrm{CDCl}_{3}\right) \delta 7.85(\mathrm{~d}, J 8.3 \mathrm{~Hz}, 2 \mathrm{H})$, 7.40-7.37 (m, 2H), 7.24-7.18 (m, 1H), 3.43 (s, 2H), 2.20 (s, 3H).

\section{2,5-Diphenyl-1,2-dihydro pyrazol-3-one (3b)}

mp 137-139 ${ }^{\circ} \mathrm{C}\left(\right.$ lit $\left.^{32} 138-140{ }^{\circ} \mathrm{C}\right)$; IR (KBr) $v_{\max } / \mathrm{cm}^{-1}$ : 3062, 2956, 1593, 1556, 1517; ${ }^{1} \mathrm{H}$ NMR (400 MHz, DMSO- $\left.d_{6}\right) \delta 11.77$ (bs, $\left.1 \mathrm{H}\right), 7.83-7.81(\mathrm{~m}, 4 \mathrm{H}), 7.50-7.46$ $(\mathrm{m}, 4 \mathrm{H}), 7.43-7.28(\mathrm{~m}, 2 \mathrm{H}), 6.02(\mathrm{~s}, 1 \mathrm{H})$; Mass $(\mathrm{CI}, \mathrm{m} / \mathrm{z})$ $237.2(\mathrm{M}+1,100)$.
${ }^{1} \mathrm{H}$ NMR (400 MHz, $\left.\mathrm{CDCl}_{3}\right) \delta 7.95(\mathrm{~d}, J 8.4 \mathrm{~Hz}, 2 \mathrm{H})$, 7.8-7.7 (m, 2H), 7.45-7.35 (m, 5H), 7.20-7.10 (m, 1H), $3.8(\mathrm{~s}, 2 \mathrm{H})$.

5-Methyl-1,2-dihydropyrazol-3-one (3c)

mp 222-224 ${ }^{\circ} \mathrm{C}\left(\operatorname{lit}^{33} 223-224^{\circ} \mathrm{C}\right)$; IR (KBr) $v_{\max } / \mathrm{cm}^{-1}$ : 2991, 1614, 1556, 1504, 1454; ${ }^{1} \mathrm{H}$ NMR (400 MHz, DMSO- $\left.d_{6}\right) \delta 10.20(\mathrm{bs}, 2 \mathrm{H}), 5.21(\mathrm{~s}, 1 \mathrm{H}), 2.08(\mathrm{~s}, 3 \mathrm{H})$; ${ }^{13} \mathrm{C}$ NMR $\left(50 \mathrm{MHz}, \mathrm{DMSO}-d_{6}\right) \delta 161.3,140.0,89.0,11.2$; Mass (CI, $m / z) 99(\mathrm{M}+1,100)$.

\section{5-Phenyl-1,2-dihydro pyrazol-3-one (3d)}

mp 235-237 ${ }^{\circ} \mathrm{C}\left(\operatorname{lit}^{32} 236-238^{\circ} \mathrm{C}\right)$; IR (KBr) $v_{\max } / \mathrm{cm}^{-1}$ : 3120, 1620, 1598, 1552, 1510; ${ }^{1} \mathrm{H}$ NMR (400 MHz, DMSO- $\left.d_{6}\right) \delta 12.0(\mathrm{bs}, 1 \mathrm{H}), 9.90(\mathrm{bs}, 1 \mathrm{H}), 7.66-7.64(\mathrm{~m}$, 2H), 7.41-7.38 (m, 2H), 7.31-7.27 (m, 1H), 5.88 (s, 1H); Mass (CI, $m / z) 161.3(\mathrm{M}+1,100)$.

2-(2,4-Dinitro phenyl)-5-methyl-1,2-dihydro pyrazol-3one $(3 \boldsymbol{e})$

IR $(\mathrm{KBr}) v_{\max } / \mathrm{cm}^{-1}: 3124,1593,1522 ;{ }^{1} \mathrm{H}$ NMR (400 $\left.\mathrm{MHz}, \mathrm{CDCl}_{3}\right) \delta 11.30$ (bs, 1H), 9.07 (s, 1H), 8.40 (d, J 9.8 Hz, 1H), 7.99 (d, J 9.8 Hz, 1H), 5.37 (s, 1H), 2.12 (s, 3H); Mass (CI, $m / z) 265.5(\mathrm{M}+1,100)$.

2-(2,4-Dinitro phenyl)-5-phenyl-1,2-dihydro pyrazol-3one $(3 f)$

IR $(\mathrm{KBr}) v_{\max } / \mathrm{cm}^{-1}: 3120,1598,1552 ;{ }^{1} \mathrm{H}$ NMR (400 $\left.\mathrm{MHz}, \mathrm{CDCl}_{3}\right) \delta 11.35$ (bs, 1H), 8.89 (s, 1H), 8.41 (d, J $9.7 \mathrm{~Hz}, 1 \mathrm{H}), 8.05$ (d, J 9.7 Hz, 1H), 7.67-7.64 (m, 2H), 7.41-7.38 (m, 3H), $5.36(\mathrm{~s}, 1 \mathrm{H})$; Mass (CI, m/z) 327.2 $(\mathrm{M}+1,100)$.

3-Methyl-5-oxo-2,5-dihydro-1H-pyrazole-1-carboxamide ${ }^{34}$ (3g)

$\mathrm{mp} 228-230^{\circ} \mathrm{C}$; IR $(\mathrm{KBr}) v_{\max } / \mathrm{cm}^{-1}: 3120,3057,1620$, 1598, 1548; ${ }^{1} \mathrm{H}$ NMR (400 MHz, DMSO- $d_{6}$ ) $\delta$ 8.0-7.0 (bs, 3H), 5.25 (s, 1H), 2.15 (s, 3H); Mass (CI, m/z) 142.0 $(\mathrm{M}+1,100)$.

5-Oxo-3-phenyl-2,5-dihydro-1H-pyrazole-1-carboxamide ${ }^{35}$ (3h)

$\operatorname{mp} 178-180^{\circ} \mathrm{C} ; \mathrm{IR}(\mathrm{KBr}) v_{\max } / \mathrm{cm}^{-1}: 3115,1616,1598 ;{ }^{1} \mathrm{H}$ NMR (200 MHz, DMSO- $\left.d_{6}\right) \delta$ 8.0-7.65 (bs, 3H), 7.60-7.35 (m, 5H), 5.70 (s, 1H); Mass (CI, m/z) $204(\mathrm{M}+1,100)$.

2-(4-Chlorophenyl)-5-methyl-1,2-dihydro pyrazol-3-one $e^{27}$ (3i) mp $167-169^{\circ} \mathrm{C}$; IR (KBr) $v_{\max } / \mathrm{cm}^{-1}: 1670,1591,1562$; ${ }^{1} \mathrm{H}$ NMR (400 MHz, $\left.\mathrm{CDCl}_{3}\right) \delta 7.86(\mathrm{~d}, J 7.8 \mathrm{~Hz}, 2 \mathrm{H}), 7.37$ (d, J7.8 Hz, 2H), 3.41 (s, 2H), 2.19 (s, 3H); Mass (CI, m/z) $209.0\left(\mathrm{M}^{+}, 100\right), 211(\mathrm{M}+2,30)$. 
Spectral data for 3-[(2,4-dinitro phenyl) hydrazono]butyric acid ethyl ester (3ee)

IR (KBr) $v_{\max } / \mathrm{cm}^{-1}: 3313,3105,2981,1726,1620$, 1596; ${ }^{1} \mathrm{H}$ NMR (400 MHz, $\mathrm{CDCl}_{3}$ ) $\delta 11.20$ (bs, 1H), 9.05 (s, 1H), $8.38(\mathrm{~d}, J 9.8 \mathrm{~Hz}, 1 \mathrm{H}), 7.98(\mathrm{~d}, J 9.8 \mathrm{~Hz}, 1 \mathrm{H}), 4.25$ (m, 2H), 3.40 (s, 2H), 2.20 (s, 3H), 1.25 (t, J 7.0 Hz, 3H); Mass (ESI, $\mathrm{m} / z) 311.2\left(\mathrm{M}^{+}, 100\right)$.

Spectral data for 3-[(2,4-dinitro phenyl) hydrazono]-3phenyl propionic acid ethyl ester (3ff)

IR (KBr) $v_{\max } / \mathrm{cm}^{-1}: 3311,3103,2980,1730,1619 ;{ }^{1} \mathrm{H}$ NMR (400 MHz, DMSO- $\left.d_{6}\right) \delta 11.40(\mathrm{bs}, 1 \mathrm{H}), 8.85(\mathrm{~s}, 1 \mathrm{H})$, $8.43(\mathrm{~d}, J 9.7 \mathrm{~Hz}, 1 \mathrm{H}), 8.10(\mathrm{~d}, J 9.7 \mathrm{~Hz}, 1 \mathrm{H}), 7.97-7.94$ (m, 2H), 7.51-7.48 (m, 3H), 4.19-4.14 (m, 4H), $1.20(\mathrm{t}, J$ $7.0 \mathrm{~Hz}, 3 \mathrm{H})$; Mass (ESI, $\mathrm{m} / \mathrm{z}) 372.4\left(\mathrm{M}^{+}, 100\right)$.

Preparation of 3-[4-(2-ethoxycarbonyl ethyl)-3-methyl-5oxo-1-phenyl-4,5-dihydro-1H-pyrazol-4-yl]propionic acid ethyl ester (4)

To a stirred solution of sodium hydride $(10 \mathrm{mmol})$ in DMF $(15 \mathrm{~mL})$ was added compound $\mathbf{3 a}(5 \mathrm{mmol})$ at $10^{\circ} \mathrm{C}$. Then methyl acrylate $(10 \mathrm{mmol})$ was added dropwise and the mixture was stirred for $10 \mathrm{~h}$. After completion of the reaction the mixture was poured into crushed ice $(20 \mathrm{~g})$ and acidified with dilute $\mathrm{HCl}$ with vigorous stirring until the $\mathrm{pH}$ of the mixture reach 3.0. Then the mixture was extracted with ethyl acetate $(2 \times 20 \mathrm{~mL})$. The organic layers were collected, combined, washed with water $(2 \times 20 \mathrm{~mL})$, dried over anhydrous $\mathrm{Na}_{2} \mathrm{SO}_{4}$ and concentrated. The residue was purified by column chromatography (1:19 ethyl acetate - petroleum ether) to give the desired compound; IR (KBr) $v_{\max } / \mathrm{cm}^{-1}: 1740$, 1598; ${ }^{1} \mathrm{H}$ NMR (200 MHz, $\left.\mathrm{CDCl}_{3}\right) \delta$ 7.90-7.20 (m, 5H), $3.65(\mathrm{~s}, 6 \mathrm{H}), 2.30-2.07(\mathrm{~m}, 11 \mathrm{H})$; Mass $(\mathrm{CI}, \mathrm{m} / \mathrm{z}) 347$ $(\mathrm{M}+1,100 \%)$.

Preparation of 1-methyl-4,8-dioxo-3-phenyl-2,3-diaza spiro[4.5]dec-1-ene-7-carboxylic acid ethyl ester (5)

To a solution of sodium methoxide $(250 \mathrm{mg}, 10 \mathrm{mmol})$ in dry methanol $(50 \mathrm{~mL})$ was added diester 4 (3.46 g, $10 \mathrm{mmol})$ at $25{ }^{\circ} \mathrm{C}$ with stirring. The mixture was then heated to reflux for $6 \mathrm{~h}$, cooled to room temperature and poured into crushed ice with vigorous stirring. The mixture was then neutralized by using dil $\mathrm{HCl}$ until $\mathrm{pH}$ become 6 . The mixture was then extracted with ethyl acetate $(2 \times 25 \mathrm{~mL})$, organic layers were collected, combined, washed with water $(2 \times 20 \mathrm{~mL})$, dried over anhydrous $\mathrm{Na}_{2} \mathrm{SO}_{4}$ and concentrated. The residue was purified by column chromatography (1:9 ethyl acetate:petroleum ether) to give the desired compound; IR (KBr) $v_{\max } / \mathrm{cm}^{-1}$ : $1735,1713,1598 ;{ }^{1} \mathrm{H}$ NMR $\left(200 \mathrm{MHz}, \mathrm{CDCl}_{3}\right) \delta$ 7.90-7.20 (m, 5H), 4.60 (bs, 1H), 3.65 (s, 3H), 2.35-2.05 (m, 9H); Mass (CI, $\mathrm{m} / z) 315(\mathrm{M}+1,100 \%)$.

Preparation of 4-methyl-2-phenyl-2,3-diaza spiro[4.5] dec-3-ene-1,8-dione (6)

To a solution of 1-methyl-4,8-dioxo-3-phenyl-2,3diaza spiro[4.5]dec-1-ene-7-carboxylic acid ethyl ester 5 $(5 \mathrm{mmol})$ in DMSO $(25 \mathrm{~mL})$ was added $\mathrm{NaCl}(30 \mathrm{mmol})$ and the mixture was stirred at $150{ }^{\circ} \mathrm{C}$ for $5 \mathrm{~h}$. The volume of the mixture was then reduced to half under vacuum and diluted with water. The solid separated was filtered, collected and purified using column chromatography (1:9 ethyl acetate:petroleum ether) to give the desired compound; IR $(\mathrm{KBr}) v_{\max } / \mathrm{cm}^{-1}: 1710,1595 ;{ }^{1} \mathrm{H}$ NMR $\left(200 \mathrm{MHz}, \mathrm{CDCl}_{3}\right) \delta$ 7.70-7.24 (m, 5H), 2.31 (s, 3H), 2.27-2.10 (m, 8H); ${ }^{13} \mathrm{C}$ NMR (50 MHz, $\left.\mathrm{CDCl}_{3}\right) \delta 207.5$, 152.1, 140.1, 138.9, 132.2, 128.2, 127.3, 126.3, 125.6, 125.4, 123.7, 109.9, 34.8, 29.6, 13.2; Mass (CI, $\mathrm{m} / \mathrm{z}$ ) $257(\mathrm{M}+1,100)$.

\section{Acknowledgments}

The authors thank Mr. M. N. Raju, the chairman of M.N.R. Educational Trust for his constant encouragement and Dr B. Das of IICT, Hyderabad for spectral data.

\section{References}

1. Kees, K. L.; Fitzgerald, Jr. J. J.; Steiner, K. E.; Mattes, J. F.; Mihan, B.; Tosi, T.; Mondoro, D.; McCalebr, M. L.; J. Med. Chem. 1996, 39, 3920.

2. Education in Chemistry July 2005 - Feature - Pain relief: from coal tar to paracetamol, http://www.rsc.org/Education/EiC/ issues/2005July/painrelief.asp, acessed in December 2007.

3. Goder, K.; Zur Einführung synthetischer Schlafmittel in die Medizinim 19. Jahrhundert, Marburger Schriften zur Medizingeschichte; Lang Verlag: Frankfurt/M., Bern, New York, vol. 18, 1985.

4. Watanabe, T.; Yuki, S.; Egawa, M.; Nishi, H.; J. Pharmacol. Exp. Ther. 1994, 268, 1597.

5. Kawai, H.; Nakai, H.; Suga, M.; Yuki, S.; Watanabe, T.; Saito, K. I.; J. Pharmacol. Exp. Ther. 1997, 281, 921.

7. Kimata, A.; Nakagawa, H.; Ohyama, R.; Fukuuchi, T.; Ohta, S.; Suzuki, T.; Miyata, N.; J. Med. Chem. 2007, 50, 5053.

8. Pericherla, S.; Mareddy, J.; D. P., Geetha Rani; Gollapudi, P. V.; Pal, S.; J. Braz. Chem Soc. 2007, 18, 384; Pal, S.; Tetrahedron 2006, 62, 3171.

9. Pal, S.; Bindu, P.; Venna, P. R.; Dubey, P. K.; Lett. Org. Chem. 2007, 4, 292.

10. Jayaselli, J.; Cheemala, J. M. S.; Rani D. P. G.; Pal, S.; J. Braz. Chem. Soc. 2008, 19, 509; Chakraborty, S.; Ghosh, S.; Cheemala, 
J. M. S.; Jayaselli, J.; Pal, S.; Mukherjee, A. K.; Z. Kristallogr. 2007, 222, 437.

11. Teruo, O.; Yoshio, K.; Hiroshi, M.; Hitoshi, Y.; Yoshito, A.; Hirokazu, T.; European Patent Application EP 0531901A2, March 17, 1993.

12. Faraci, W. S.; Welch, Jr., W. M.; US Patent Application US 6,005,109, December 21, 1999.

13. Elguero, J. In Comprehensive Heterocyclic Chemistry. K. T. Potts, Ed.; Pergamon Press: Oxford, 1984, vol. 5, p 167.

14. Selby, T. P.; Stevenson, T. M.; US Patent Application US 5,670,455, September 23, 1997.

15. Tietze, L. F.; Stteinmetz, A.; Balkenhohl, F.; Bioorg. Med. Chem. Lett. 1997, 7, 1303.

16. Flores, A. F. C.; Zanatta, N.; Rosa, A.; Brondani, S.; Martins, M. A. P.; Tetrahedron Lett. 2002, 43, 5005.

17. Tietze, L.; Steinmetz, A.; Synlett 1996, 667.

18. Wiley, R. H.; Wiley, P. Pyrazolones, Pyrazolidones and Derivatives; Interscience Publishers, A Division of John Wiley and Sons: New York, 1964.

19. Yamamoto, Y.; Shirakawa, N.; Takano, S.; Kawai, Y.; US Patent Application 5663365, September 02, 1997.

20. Kuffner, K.; Meier, E.; Glockner, H.; US Patent Application 3956311, May 11, 1976

21. Makhija, M. T.; Kasliwal, R. T.; Kulkarni, V. M.; Neamati, N.; Bioorg. Med. Chem. 2004, 12, 2317.

22. Ruiter, J. D.; Carter, D. A.; Avledge, W. S.; Sullivan, P. J.; J. Heterocycl. Chem. 1987, 24, 149; Phadtane, S. K.; Kamat, S. K.; Panse, G. T.; Indian J. Chem. 1980, 19B, 212; Khan, M. A.; Cosenza, A. G.; J. Heterocycl. Chem. 1982, 19, 1077; Katritzky, A. R.; Barczynski, P.; Ostercamp, D. L.; J. Chem. Soc., Perkin Trans. 1987, 2, 969.
23. Verma, R. S.; Green Chem. 1999, 1, 43.

24. Kidwai, M.; Mothsra, P.; Ind. J. Chem. Sec. B 2006, 45B, 2330.

25. Pal, S.; Khan, M. A.; Bindu, P.; Dubey, P. K. ; Beilstein J. Org. Chem. 2007, 3, 35.

26. Mojtahedi, M. M.; Jalali, M. R.; Abaee, M. S.; Bolourtchian, M.; Heterocyclic Commun. 2006, 12, 225. We thank one of the reviewer for bringing this report to our notice.

27. Duan, X. M.; Fan, M. L.; Zheng, P. W.; Li, J. S.; Huang, P. M.; Acta Crystallogr., Sect. E: Struct. Rep. Online 2006, E62, o2019.

28. Katritzky, A. R., Barczynski, P.; Ostercamp, D. L.; J. Chem. Soc., Perkin Trans. 1987, 2, 969.

29. Fox, M. A.; Whitesell, J. K.; Nucleophilic Addition and Substitution at Carbonyl Group, Organic Chemistry, $3^{\text {rd }}$ ed., Jones \& Bartlett Publishers: Boston, 2004, ch. 12, pp 571.

30. Pavlov, P.; Goleneva, A. F.; Lesnov, A. E.; Prokhorova, T. S.; Pharm. Chem. J. 1998, 32, 370.

31. Chande, M. S.; Barve, P. A.; Suryanarayan, V.; J. Heterocycl. Chem. 2007, 44, 49.

32. Omar, M. T.; Synthesis 1981, 742.

33. Jung, J.-C.; Watkins, E. B.; Avery, M. A.; Tetrahedron 2002 , $58,3639$.

34. Rajendran, G.; Asian J. Chem. 1999, 11, 153.

35. De, S. C.; Dutt, N. C.; J. Indian Chem. Soc. 1928, 5, 459.

Received: January 7, 2008

Web Release Date: July 30, 2008 